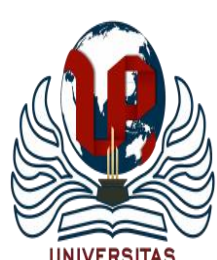

UNIVERSITAS

Jurnal Basicedu Volume 4 Nomor 4 Tahun 2020 Halaman 1176 - 1185

JURNAL BASICEDU

Research \& Learning in Elementary Education

https://jbasic.org/index.php/basicedu

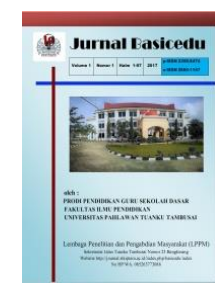

\title{
Pengembangan Bahan Ajar Membaca Pemahaman Menggunakan Pojok Literasi pada Siswa di Kelas IV Sekolah Dasar
}

\author{
Taufina ${ }^{1}$, Ahmad Zikri \\ Pendidikan Dasar. FIP Universitas Negeri Padang, Sumatera Barat, Indonesia ${ }^{1}$ \\ Pendidikan Dasar, FIP Universitas Negeri Padang, Sumatera Barat, Indonesia ${ }^{2}$ \\ E-mail: taufina_taufik@yahoo.co.id zikria79@yahoo.com² $^{2}$
}

\begin{abstract}
Abstrak
Penelitian ini bertujuan untuk menjelaskan proses pengembangan bahan ajar membaca pemahaman dengan menggunakan pojok literasi pada siswa kelas IV Sekolah Dasar. Jenis penelitian ini adalah penelitian pengembangan (Research and Developement). Subjek uji coba adalah peserta didik kelas IV SDN 13 Batang Gasan dan Penyebaran di SDN 01 Batang Gasan. Berdasarkan hasil uji coba kevalidan dapat dilhat dari validasi isi, bahasa, tampilan, keseluruhan 3,7 dengan kategori sangat valid. Pratikalitas bahan ajar dilihat dari respon pendidik dan respon peserta didik memiliki persentase 89 dengan kategori sangat praktis, sedangkan efektifitas bahan ajar 87,65\%. Dapat disimpulkan bahwa bahan ajar valid, praktis dan efektif pada kelas IV Sekolah Dasar.
\end{abstract}

Kata kunci: bahan ajar, membaca pemahaman, pojok literasi

Abstract

This study aims to explain the process of developing reading comprehension teaching materials using the literacy corner for fourth grade elementary school students. This type of research is research and development (Research and Development). The test subjects were fourth grade students of SDN 13 Batang Gasan and the distribution at SDN 01 Batang Gasan. Based on the results of the validity trial, it can be seen from the validation of content, language, appearance, overall 3.7 with very valid categories. The practicality of teaching materials seen from the responses of educators and the responses of students has a percentage of 89 in the very practical category, while the effectiveness of teaching materials is $87.65 \%$. It can be concluded that the teaching materials are valid, practical and effective in grade IV of Elementary School.

Keywords: teaching materials, reading comprehension, literacy corner

Copyright (c) 2020 Taufina, Ahmad Zikri

$\triangle$ Corresponding author

Address : Air Tawar Padang

Email: : zikria79@yahoo.com

ISSN 2580-3735 (Media Cetak)

Phone : 089531307164

ISSN 2580-1147 (Media Online)

DOI: https://doi.org/10.31004/basicedu.v4i4.523 
1177 Pengembangan Bahan Ajar Membaca Pemahaman Menggunakan Pojok Literasi pada Siswa di Kelas IV Sekolah Dasar - Taufina, Ahmad Zikri

DOI: https://doi.org/10.31004/basicedu.v4i4.523

\section{PENDAHULUAN}

Pendidikan merupakan suatu proses dalam menghasilkan generasi penerus bangsa yang berkualitas baik dari segi sikap, keterampilan, dan pengetahuan. Oleh karena itu pemerintah selalu berupaya untuk meningkatkan kualitas pendidikan di Indonesia (Suwardana, 2018). Upaya yang telah dilakukan pemerintah untuk meningkatkan mutu pendidikan salah satunya dengan meningkatkan anggaran pendidikan, perbaikan fasilitas, peningkatan mutu guru, dan dikeluarkannya Undang-undang tentang Sistem Pendidikan Nasional pada tahun 2013, dimana pengembangan kurikulum 2013 dilakukan sebagai penyempurnaan Kurikulum Tingkat Satuan Pendidikan (KTSP) tahun 2006 yang dikenal dalam pembelajaran tematik terpadu (Kemendikbud, 2013).

Baru-baru ini dikeluarkannya Permendikbud 57 tahun 2014 tentang Standar Isi dan Kerangka Dasar Kurikulum SD/MI yang menyebutkan bahwa "pelaksanaan Kurikulum 2013 pada SD/MI dilakukan melalui pembelajaran dengan pendekatan tematik terpadu dari kelas I sampai VI" (Weriyanti, Firman, Taufina, \& Zikri, 2020). Menurut Mulyasa (2013) "pengembangan kurikulum 2013 bertujuan untuk menghasilkan insan indonesia yang produktif, inofatif, dan kreatif melalui penguatan sikap, keterampilan, dan pengetahuan yang terintegrasi (Mulyasa, 2013).

Salah satu kegiatannya yaitu dengan menerapkan literasi membaca di Sekolah Dasar. Literasi membaca di SD dapat dilakukan dengan menggunakan pojok literasi (Nopilda \& Kristiawan, 2018). Pojok literasi merupakan cara yang digunakan guru dalam mengajarkan literasi membaca yang menyenangkan, komunikatif, dan menarik (Batubara \& Ariani, 2018).

Sekolah Dasar memiliki peran dalam pelaksanaan program PPK. Hal ini menunjukkan bahwa sekolah dasar sudah memenuhi kualifikasi dalam melaksanakan berkarakter (Bentri, Adree, \& Putra, 2014). Dengan adanya amanah yang diberikan oleh Menteri Pendidikan dan Kebudayaan tersebut, menjadikan peserta didik memiliki minat dan tanggung jawab penuh untuk menjadikan sekolah berkarakter. Salah satunya dengan menggiatkan gemar membaca yang digalakkan setiap hari (Muhammadi, Taufina, \& Chandra, 2018).

Membaca merupakan salah satu keterampilan berbahasa. Membaca adalah suatu proses interaksi memahami lambang bahasa melalui berbagai strategi untuk memahami makna dari yang tertulis, melibatkan aktivitas visual, berpikir, psikolinguistik, dan metakognitif (Ratih \& Taufina, 2019; Taufina, 2017). Suarni (2019) mengungkapkan bahwa membaca adalah proses pengolahan informasi yang dilaksanakan oleh pembaca dengan menggunakan informasi dalam bacaan dan pengetahuan yang relevan dengan informasi (Suarni, Taufina, \& Zikri, 2019).

Selain itu, Chandra (2018) mengungkapkan bahwa definisi membaca mencakup (1) membaca merupakan suatu proses, (2) membaca adalah strategis, dan (3) membaca merupakan interaktif. Jadi, dapat disimpulkan bahwa membaca merupakan proses melisankan lambang bahasa yang melibatkan aktivitas visual, berpikir, psikolinguistik, dan metakognitif dengan berbagai 
1178 Pengembangan Bahan Ajar Membaca Pemahaman Menggunakan Pojok Literasi pada Siswa di Kelas IV Sekolah Dasar - Taufina, Ahmad Zikri

DOI: https://doi.org/10.31004/basicedu.v4i4.523

strategi guna memperoleh informasi dari bacaan (Chandra, Mayarnimar, \& Habibi, 2018).

Berdasarkan pengamatan dan wawancara di SDN 13 Batang Gasan selama 2 minggu, ditemukan beberapa kebutuhan dan permasalahan utama. Pertama masih banyaknya peserta didik yang belum memiliki minat penuh terhadap membaca. Hal ini terbukti dengan rendahnya minat membaca peserta didik di sekolah. Kedua sekolah seharusnya memiliki pojok literasi sendiri, namun kurangnya penerapan pojok literasi di Sekolah Dasar. Ketiga, sekolah sebagai pelaksana Penguatan Pendidikan Karakter (PPK) menjadikan kegiatan literasi (Nur, 2018). Namun kegiatan literasi belum terlihat dilaksanakan di sekolah tersebut. Keempat, masih banyaknya perilaku negatif peserta didik yang diakibatkan karena bacaan dan tontonan yang tidak mendidik. Seperti kasus murid menantang guru di sekolah di SMP PGRI Wringinanom (http://news.detik.com). Padahal sebelum adanya tontonan dari gadget jarang terjadi kasus seperti ini.

Berdasarkan permasalahan tersebut, perlu adanya upaya dalam meningkatkan literasi anak. Salah satunya dengan membuat pojok literasi. Dengan tersedianya pojok literasi, diharapkan peserta didik dapat menyalurkan minat membacanya, karena ia merasa bahwa pojok literasi penting dalam menambah ilmu pengetahuan. Hal ini sesuai dengan Tugas Pokok Guru dalam Permendikbud Nomor 15 Tahun 2018 salah satunya terdapat pada tugas pokok keempat yaitu membimbing dan melatih peserta didik. Oleh sebab itu, penulis tertarik untuk menyusun rancangan aktualisasi ini dengan judul
"Pengembangan Bahan Ajar Literasi Membaca dengan menggunakan Pojok Literasi sebagai Upaya Revolusi Mental Siswa SD”.

\section{METODE}

Pengembangan bahan ajar menggunakan pendekatan 4D. Pendekatan ini dikembangkan oleh Sugiyono (Sugiyono, 2013). Tahap-tahap pendekatan 4-D antara lain: pendefinisian (define), perancangan (design), pengembangan (develop), dan penyebaran (disseminate) (Prastowo, 2013). Akan tetapi, karena keterbatasan tenaga, biaya, dan waktu penulis, dilakukan pada skala terbatas yaitu untuk uji coba di kelas IV SDN 13 Batang Gasan dan Penyebaran dilakukan di Kelas IV SDN 01 Batang Gasan sesuai dengan kebutuhan penulis.

Pendekatan pengembangan tersebut dipilih karena memiliki kelebihan yang dapat dijadikan sebagai dasar dan acuan dalam pemilihan pendekatan yang dilakukan. Kelebihan yang dimiliki oleh pendekatan 4D antara lain: (1) lebih tepat digunakan sebagai dasar untuk pengembangan bahan ajar, (2) uraiannya terlihat lebih lengkap dan sistematis, dan (3) dalam pengembangannya melibatkan penilaian para ahli, sehingga sebelum dilakukan uji coba di lapangan bahan ajar telah dilakukan revisi berdasarkan penilaian, saran, dan masukan dari para ahli.

\section{Tahap Pendefinisian (Define)}

Tahap ini bertujuan untuk menetapkan dan mendefinisikan syarat-syarat yang dibutuhkan dalam pengembangan bahan ajar. Tahap ini dilakukan dengan menganalisis tujuan dalam batasan materi pembelajaran yang dikembangkan. Tahap pendefinisian bertujuan 
1179 Pengembangan Bahan Ajar Membaca Pemahaman Menggunakan Pojok Literasi pada Siswa di Kelas IV Sekolah Dasar - Taufina, Ahmad Zikri

DOI: https://doi.org/10.31004/basicedu.v4i4.523

untuk menetapkan dan mendefinisikan syaratsyarat pembelajaran yang sesuai dengan tujuan penelitian yaitu pengembangan bahan ajar menggunakan pojok literasi. Terdapat tiga langkah yang dilakukan dalam tahap pendefinisian, yaitu:

a. Analisis kurikulum

Menganalisis kurikulum bertujuan untuk mengetahui apakah materi yang diajarkan sudah sesuai dengan kompetensi yang diharapkan. Berdasarkan kurikulum 2013, kompetensi dinilai pada peserta didik mencakup tiga ranah yakni sikap, pengetahuan dan keterampilan. Ranah sikap dipilih menjadi sikap spiritual dan sikap sosial. Sedangkan muatan pembelajaran pada pelaksanaan kurikulum 2013 harus dilakukan dengan mengintegrasikan kompetensi dasar dari berbagai mata pelajaran yaitu intradisipliner, interdisipliner, multidisipliner, dan transdisipliner.

Tujuan ini sejalan dengan pembelajaran menggunakan pojok literasi pada pembelajaran tematik SD. Dalam mencapai tujuan tersebut, proses belajar dimulai dari melakukan pembentukan kelompok, melaksanakan kegiatan kegiatan literasi di pojok literasi, kemudian merefleksikan kegiatan selama proses pembelajaran. Adapun analisis kompetensi dasar, indikator, dan tujuan pembelajaran kelas IV SD pada tema 4 berbagai pekerjaan pada pembelajaran. b. Analisis kebutuhan

Analisis kebutuhan difokuskan pada analisis permasalahan yang terdapat pada bahan ajar yang digunakan guru selama proses pembelajaran. Setelah dilakukan analisis terhadap salah satu bahan ajar yang diberikan kepada peserta didik ternyata bahan ajar tersebut adalah bahan ajar yang belum dikembangkan dan diperjualbelikan di pasaran. Penggunaan bahan ajar belum dapat membantu peserta didik dalam memahami materi yang diajarkan guru.

Adapun kelemahan yang ditemukan pada bahan ajar sebagai berikut: 1) pada aspek pencapaian indikator, belum tercapainya indikator yang ingin dikembangkan setelah melakukan pembelajaran, 2) aspek isi kuramg terlihat kegiatan pembelajaran tematik SD, 3) aspek bahasa spasi tulisan kurang disesuaikan dengan kebutuhan peserta didik, 4) aspek tampilan kurang banyak ilustrasi gambar dan gambar tidak diberikan warna.

Melihat analisis bahan ajar yang digunakan peserta didik tidak sesuai dengan tematik SD kurikulum 2013. Perbedaan dengan pembelajaran tematik SD KTSP dengan tematik SD Kurikulum 2013 terletak pada KTSP pembelajaran berdiri sendiri, sedangkan kurikulum 2013 telah dipadukan kedalam tema pembelajaran.

Berdasarkan hasil analisis kebutuhan ini peserta didik membutuhkan bahan ajar menuntun peserta didik dan memberikan kesempatan secara mandiri atau kerjasama 
1180 Pengembangan Bahan Ajar Membaca Pemahaman Menggunakan Pojok Literasi pada Siswa di Kelas IV Sekolah Dasar - Taufina, Ahmad Zikri

DOI: https://doi.org/10.31004/basicedu.v4i4.523

dalam pembelajaran tematik SD sehingga tercipta pembelajaran yang diajarkan menjadi bermakna bagi peserta didik.

\section{Tahap Perancangan (Desaign)}

Tahap perancangan adalah merancang bahan ajar tematik menggunakan pojok literasi di kelas IV SD semester satu. Adapun hal-hal yang dirancang dalam pengembangan bahan ajar ini adalah:

a. Bahan ajar dirancang sesuai tuntutan SK dan $\mathrm{KD}$, kesesuaian materi dan tuntutan kurikulum yang berlaku.

b. Pemilihan sumber belajar (teks sesuai dengan kondisi siswa di lingkungan sekitar).

c. Rancangan RPP dikembangkan berdasarkan langkah-langkah dan prinsip pengembangan RPP sesuai Permendiknas No.22 Tahun 2016.

d. Rancangan materi pembelajaran yang sesuai dengan tahapan proses membaca pemahaman.

e. Cara penyajian materi yang berpengaruh dalam pengembangan bahan ajar menggunakan pojok literasi.

\section{Tahap pengembangan (develop)}

Tahap pengembangan (develop) meliputi uji validitas, praktikalitas, dan efektivitas seperti yang dijabarkan berikut ini.

\section{a. Validitas Bahan Ajar}

Validitas dilakukan oleh peneliti yang di validasi oleh ahli di bidang pembelajaran tematik SD. Tujuan kegiatan ini adalah untuk mendapatkan masukan terhadap keseluruhan isi materi yang terdapat dalam rancangan bahan ajar tematik yang sudah dirancang. Selanjutnya divalidasi oleh ahli di bidang desain pembelajaran yang bertujuan untuk mendapatkan masukan mengenai kesesuaian dengan kegiatan pojok literasi yang digunakan dengan bentuk rancangan bahan ajar yang dikembangkan untuk pembelajaran tematik di kelas IV.

Ada tiga validasi yang digunakan oleh peneliti dalam pengembangan bahan ajar, yaitu:

1) Validitas isi (content validity), yaitu apakah bahan ajar yang dirancang sesuai dengan pembelajaran tematik.

2) Validitas bahasa (language validity), yaitu sesuai dengan Bahasa Indonesia dan EYD yang berlaku.

3) Validitas konstruk (construct validity), yaitu kesesuaian komponen-komponen bahan ajar dengan unsur-unsur pengembangan yang sudah ditetapkan.

\section{b. Praktikalitas Bahan Ajar}

Praktikalitas merupakan tingkat keterlaksanaan bahan ajar oleh guru dan siswa. Praktikalitas bahan ajar diuji dalam proses pembelajaran melalui penggunaan bahan ajar oleh guru dan siswa. Bahan ajar yang digunakan merupakan bahan ajar yang telah divalidasi oleh validator. Uji praktikalitas bahan ajar dilakukan menggunakan angket dan lembar observasi.

Observasi dilakukan oleh dua orang pengamat, yaitu guru dan peneliti sendiri. Observer mengamati keterpakaian bahan ajar dalam proses pembelajaran dan mengisi instrumen observasi yang telah disiapkan. 
1181 Pengembangan Bahan Ajar Membaca Pemahaman Menggunakan Pojok Literasi pada Siswa di Kelas IV Sekolah Dasar - Taufina, Ahmad Zikri

DOI: https://doi.org/10.31004/basicedu.v4i4.523

Selanjutnya, observer mengisi angket keterpakaian bahan ajar pembelajaran tematik menggunakan pojok literasi. Hasil angket ini dijadikan sebagai dasar untuk melakukan perbaikan terhadap bahan ajar yang dikembangkan. Aspek keterlaksanaan pembelajaran dilihat dari hasil pengisian lembar keterlaksanaan RPP oleh dua orang observer. Respon siswa didapatkan dari hasil pengisian angket respon siswa terhadap bahan ajar pembelajaran tematik dengan menggunakan pojok literasi. Kemudian, uji coba terbatas dilakukan pada peserta siswa kelas IV SDN 13 Batang Gasan dan SDN 01 Batang Gasan.

\section{c. Efektivitas Bahan Ajar Pembelajaran}

Efektivitas bahan ajar dilakukan evaluasi hasil belajar siswa. Hal ini dilakukan dengan mengamati aktivitas dan peningkatan hasil belajar siswa dalam proses pembelajaran. Aspek aktivitas yang diamati adalah hasil belajar siswa menggunakan pojok literasi.

\section{Tahap Penyebaran (disseminate)}

Tahap penyebaran adalah tahap yang selanjutnya terhadap pengembangan bahan ajar pojok literasi pada subjek lain, misalnya di kelas lain, atau sekolah lain. Tujuannya adalah untuk menguji efektivitas penggunaan bahan ajar tersebut pada subjek yang berbeda. Bahan ajar yang dikatakan efektif jika dapat memberikan hasil yang baik terahadap hasil belajar siswa. Peneliti melakukan penyebaran bahan ajar tematik berbasis pojok literasi dalam skala terbatas yaitu di kelas IV SDN 01 Batang Gasan.

\section{HASIL DAN PEMBAHASAN}

\section{Validasi Bahan Ajar}

Bahan ajar yang telah divalidasi sebelum diberi penilaian oleh validator, diperbaiki sesuai dengan saran-saran yang diberikan oleh validator. Setelah dilakukan perbaikan bahan ajar berdasarkan saran-saran validator, kemudian validator diminta memberi penilaian pada bahan ajar yang telah direvisi.

Berdasarkan hasil validasi bahan ajar dari validator ahli dan validator praktisi dapat dilihat pada rekapitulasi berikut:

Tabel 1. Validasi Bahan Ajar

\begin{tabular}{|l|l|c|c|}
\hline No & Aspek yang Dinilai & $\begin{array}{c}\text { Rata- } \\
\text { Rata }\end{array}$ & Kategori \\
\hline 1. & Aspek isi & 3,7 & $\begin{array}{c}\text { Sangat } \\
\text { Valid }\end{array}$ \\
\hline 2. & $\begin{array}{l}\text { Aspek bahasa dan } \\
\text { keterbacaan }\end{array}$ & 3,6 & $\begin{array}{c}\text { Sangat } \\
\text { Valid }\end{array}$ \\
\hline 3. & aspek tampilan & 3,8 & $\begin{array}{c}\text { Sangat } \\
\text { Valid }\end{array}$ \\
\hline \multicolumn{2}{|c|}{ Rata-Rata } & 3,7 & $\begin{array}{c}\text { Sangat } \\
\text { Valid }\end{array}$ \\
\hline
\end{tabular}

Pada tabel di atas terlihat bahwa rata-rata validasi aspek isi dengan rata-rata validasi adalah 3,7. Aspek rata-rata validasi bahasa dan keterbacaan mencapai rata-rata yaitu 3,6. Sedangkan aspek tampilan rata-rata validasinya yaitu 3,8. Jika dirata-ratakan indeks kevalidan secara keseluruhan aspek yang dinilai mencapai 3,7. Jadi, dapat disimpulkan secara keseluruhan validasi bahan ajar dengan menggunakan pojok literasi dengan kategori sangat valid.

\section{Hasil Validasi RPP}

Validasi RPP yang dirancang kemudian 
1182 Pengembangan Bahan Ajar Membaca Pemahaman Menggunakan Pojok Literasi pada Siswa di Kelas IV Sekolah Dasar - Taufina, Ahmad Zikri

DOI: https://doi.org/10.31004/basicedu.v4i4.523

divalidasikan berdasarkan komponen penyusunan RPP oleh tiga orang validator ahli dari perguruan tinggi. Kegiatan yang dilakukan memberikan saran terhadap RPP yang dirancang. Beberapa saran validator terhadap RPP secara garis besar adalah:

RPP yang telah divalidasi sebelum diberi penilaian oleh validator, diperbaiki sesuai dengan saran-saran yang diberikan oleh validator. Setelah dilakukan perbaikan berdasarkan saran-saran validator, kemudian validator diminta memberikan penilaian pada RPP yang telah direvisi.

Tabel 2.Hasil Validasi RPP

\begin{tabular}{|c|l|c|c|}
\hline No & \multicolumn{1}{|c|}{ Aspek yang Dinilai } & $\begin{array}{c}\text { Rata- } \\
\text { rata }\end{array}$ & Kategori \\
\hline 1. & Identitas RPP & 3,7 & $\begin{array}{c}\text { Sangat } \\
\text { Valid }\end{array}$ \\
\hline 2. & $\begin{array}{l}\text { Perumusan Indikator } \\
\text { dan Tujuan } \\
\text { Pembelajaran }\end{array}$ & 3,2 & $\begin{array}{c}\text { Sangat } \\
\text { Valid }\end{array}$ \\
\hline 3. & $\begin{array}{l}\text { Pemilihan Materi } \\
\text { Pembelajaran }\end{array}$ & 3,6 & $\begin{array}{c}\text { Sangat } \\
\text { Valid }\end{array}$ \\
\hline 4. & $\begin{array}{l}\text { Metode dan } \\
\text { Langkah-Langkah } \\
\text { Pembelajaran }\end{array}$ & 3,6 & $\begin{array}{l}\text { Sangat } \\
\text { Valid }\end{array}$ \\
\hline 5. & $\begin{array}{l}\text { Pemilihan Sumber/ } \\
\text { Media Belajar }\end{array}$ & 3,7 & $\begin{array}{c}\text { Sangat } \\
\text { Valid }\end{array}$ \\
\hline 6. & Penilaian & 3,8 & $\begin{array}{c}\text { Sangat } \\
\text { Valid }\end{array}$ \\
\hline 7. & Bahasa dan Penulisan & 3,7 & $\begin{array}{c}\text { Sangat } \\
\text { Valid }\end{array}$ \\
\cline { 1 - 2 } Skor & $\mathbf{2 5}$ & $\begin{array}{c}\text { Sangat } \\
\text { Valid }\end{array}$ \\
\hline Rata-Rata & 3,5 & $\begin{array}{c}\text { Sangat } \\
\text { Valid }\end{array}$ \\
\hline \multicolumn{2}{|l|}{} & 3,6 & $\begin{array}{c}\text { Sangat } \\
\text { Valid }\end{array}$ \\
\hline
\end{tabular}

\section{Praktilikas Bahan Ajar}

Berdasarkan tabel di atas, hasil uji praktikalitas dengan menggunakan angket peserta didik diperoleh persentase sebesar $89 \%$. Berdasarkan kriteria yang telah dibuat, maka praktikalitas terhadap bahan ajar dengan menggunakan pojok literasi dinyatakan sangat praktis. Terlihat dari angket yang diisi oleh peserta didik, bahwa bahan ajar menggunakan pojok literasi mudah digunakan, mudah dipahami, menarik, dan dapat memotivasi peserta didik untuk belajar. Secara keseluruhan persentase praktikalitas dapat dilihat pada tabel berikut sebagai berikut:

Tabel 3. Hasil Persentase Keseluruhan Praktikalitas

\begin{tabular}{|c|c|c|c|c|}
\hline $\begin{array}{c}\text { Respon } \\
\text { Siswa }\end{array}$ & $\begin{array}{c}\text { Respon } \\
\text { Guru }\end{array}$ & Jumlah & $\begin{array}{c}\text { Rata- } \\
\text { Rata }\end{array}$ & $\begin{array}{c}\text { Katego } \\
\text { ri }\end{array}$ \\
\hline 89 & 89 & 178 & 89 & $\begin{array}{c}\text { Sangat } \\
\text { Praktis }\end{array}$ \\
\hline
\end{tabular}

Berdasarkan tabel di atas, hasil uji praktikalitas secara keseluruhan berupa angket respon guru dan siswa diperoleh persentase kepraktisan sebesar 89 dengan kategori sangat praktis. Demikian, bahan ajar yang dikembangkan oleh peneliti telah membantu proses pembelajaran.

\section{Efektivitas Bahan Ajar}

Hasil uji efektifitas secara keseluruhan (aktivitas dan hasil belajar peserta didik) diperoleh persentase efektifitas sebesar 87,5 dengan kategori sangat efektif. Demikian, bahan ajar yang dikembangkan oleh peneliti telah membantu meningkatkan aktivitas dan hasil belajar peserta didik.

Tabel 4. Hasil Efektivitas Bahan Ajar

\begin{tabular}{|c|c|c|c|c|}
\hline \multicolumn{2}{|c|}{ Aspek yang Dinilai } & Uji & Penyebaran & Persentase \\
\hline \multicolumn{2}{|c|}{ Aktivitas Peserta didik } & 86 & 90 & 88 \\
\hline \multirow{3}{*}{$\begin{array}{c}\text { Hasil } \\
\text { Belajar }\end{array}$} & Sikap & 81,25 & 81,83 & 81,54 \\
\hline & Pengetahuan & 96 & 91,43 & 93,7 \\
\hline & Keterampilan & 87,75 & 87,25 & 87,5 \\
\hline \multicolumn{4}{|c|}{ Skor yang Diperoleh } & 350,74 \\
\hline \multicolumn{4}{|c|}{ Persentase Efektifitas } & $\mathbf{8 7 , 6 8}$ \\
\hline \multicolumn{4}{|c|}{ Kategori } & $\begin{array}{l}\text { Sangat } \\
\text { Efektif }\end{array}$ \\
\hline
\end{tabular}


1183 Pengembangan Bahan Ajar Membaca Pemahaman Menggunakan Pojok Literasi pada Siswa di Kelas IV Sekolah Dasar - Taufina, Ahmad Zikri

DOI: https://doi.org/10.31004/basicedu.v4i4.523

\section{PEMBAHASAN}

\section{Validitas}

Pengembangan bahan ajar dengan menggunakan pojok literasi dilakukan dalam meningkatkan proses membaca pemahaman siswa. Bahan ajar dinyatakan valid apabila telah memenuhi syarat-syarat yang telah ditentukan. Menurut Sukardi (2008) validasi adalah derajat yang menunjukkan di mana suatu perangkat mengukur apa yang hendak diukur. Hasil validasi dari ahli dan praktisi dikumpulkan kemudian dianalisis untuk mencari rata-rata dari masingmasing indikator dan masing-masing aspek. Adapun validasi bahan ajar dilakukan berdasarkan beberapa aspek yaitu aspek isi, aspek kebahasaan, dan aspek tampilan.

Hasil validasi ditinjau dari aspek Isi memperoleh nilai rata-rata 3,7 dengan kategori sangat valid. Bahan ajar yang dikembangkan sudah dapat menambah wawasan dan mendorong siswa belajar lebih aktif dan mandiri dalam menyelesaikan soal di bahan ajar. Berdasarkan hasl tersebut bahan ajar yang dikembangkan telah sesuai dengan kurikulum dan tingkat perkembangan peserta didik, sehingga peserta didik sudah dapat memahami materi.

Hasil validasi pada aspek kebahasaan diperoleh rata-rata 3,6 yang termasuk ke dalam kategori sangat valid. Disimpulkan berdasarkan hasil penelitian, keterbacaan yang dirasakan peserta didik pada materi bahan ajar jelas, bahasa yang digunakan pada bahan ajar mudah dimengerti, serta sesuai dengan perkembangan bahasa peserta didik.
Hasil validasi pada aspek tampilan diperoleh rata-rata 3,8 yang termasuk ke dalam kategori sangat valid. Disimpulkan berdasarkan hasil penelitian, dari segi tampilan yang dirasakan pada cover buku, tampilan isi bahan ajar yang digunakan dapat menarik perhatian peserta didik Sekolah Dasar.

Jika dirata-ratakan indeks kevalidan secara keseluruhan aspek yang dinilai mencapai 3,7 dikategorikan sangat valid sehingga saat uji coba dan tahap penyebaran, bahan ajar berpengaruh terhadap peningkatan hasil belajar anak dari aspek sikap, pengetahuan, dan keterampilan. Hal ini sesuai Taufina (2015) yang memperoleh validasi bahan ajar dengan kategori "sangat valid" sehingga hasil uji coba bahan ajar berpengaruh signifikan terhadap peningkatan karakter kerja keraspada peserta didik. sedangkan menurut pendapat muliyardi (2006:82) bahwa "bahan ajar dikatakan valid apabila memperoleh rata-rata tingkat pencapaian $3,40<$ rerata $\leq 4,00$.

Kesimpulannya bahwa bahan ajar yang dikembangkan telah disajikan secara sistematis. selain itu bahan ajar juga dapat memberikan motivasi, dan daya tarik bagi peserta didik dalam pembelajaran. kevalidan terhadap bahan ajar menggunakan pojok literasi yang dikembangkan menandakan bahwa bahan ajar dapat digunakan sebagai sumber belajar bagi kelas IV SD.

\section{Praktikalitas}

Berdasarkan hasil pengamatan terhadap keterlaksanaan pembelajaran dengan menggunakan bahan ajar pojok literasi yang digunakan dalam uji coba memperoleh persentase 
1184 Pengembangan Bahan Ajar Membaca Pemahaman Menggunakan Pojok Literasi pada Siswa di Kelas IV Sekolah Dasar - Taufina, Ahmad Zikri

DOI: https://doi.org/10.31004/basicedu.v4i4.523

$89 \%$ dalam kategori sangat praktis. Pelaksanaan pembelajaran dikatakan sangat Praktis apabila memperoleh rentang nilai 85-100 (Purwanto, 2009).

Hasil observasi keterlaksanaan pembelajaran dengan menggunakan bahan ajar menggunakan pojok literasi ini sudah berjalan dengan baik. Meskipun pada awal kegiatan pembelajaran ada sedikit hambatan dalam kegiatan pembelajaran yaitu kurang kondusif dalam pembelajaran dikarenakan sebagian siswa ribut dan keluar masuk kelas. Namun untuk pertemuan berikutnya guru memberikan solusi dari hambatan tersebut dan memperbaiki kekurangan-kekurangan yang terjadi dan mengarahkan peserta didik dalam menyelesaikan tugas yang diberikan baik secara mandiri maupun berkelompok secara tepat waktu.

\section{Efektivitas}

Aspek efektivitas dapat dilakukan apabila produk tersebut sudah valid dan praktis. Efektivitas untuk penelitian ini adalah untuk melihat seberapa besar kegunaan dan manfaat bahan ajar menggunakan pojok literasi ini dalam meningkatkan aktivitas dan hasil belajar peserta didik.

Peneliti dan guru mengamati bahwa motivasi peserta didik muncul selama proses pembelajaran yaitu peserta didik aktif dalam menyelesaikan latihan pada bahan ajar, memperhatikan guru ketika menjelaskan materi, bertanya jika mengalami kesulitan, dan bersemangat dalam setiap pembelajaran. Motivasi timbul karena ketertarikan peserta didik terhadap penerapan bahan ajar yang mengajak peserta didik belajar sesuai kehidupan nyata peserta didik, sehingga memudahkan peserta didik memahami materi.

\section{SIMPULAN}

Penelitian ini merupakan penelitian pengembangan yang menghasilkan bahan ajar menggunakan pojok literasi. Berdasarkan hasil penelitian, maka peneliti dapat menyimpulkan beberapa hal sebagai berikut:

1. Bahan ajar menggunakan pojok literasi yang dihasilkan pada penelitian pengembangan sudah valid baik dari aspek isi, bahasa dan tampilan dengan validitas 3,7 kategori sangat valid.

2. Bahan ajar yang dikembangkan sudah memenuhi kriteria praktis baik dari aspek kemudahan penggunaan dan implementasi oleh peserta didik dengan persentase $89 \%$.

3. Bahan ajar menggunakan pojok literasi telah efektif dari segi aktivitas siswa, aspek pengetahuan, aspek sikap, aspek keterampilan membaca pemahaman dengan rata-rata 87,68 kategori sangat efektif.

\section{DAFTAR PUSTAKA}

Batubara, H. H., \& Ariani, D. N. (2018). Implementasi Program Gerakan Literasi Sekolah Di Sekolah Dasar Negeri Gugus Sungai Miai Banjarmasin. Jurnal Pendidikan Sekolah Dasar, 4(1), 15. https://doi.org/10.30870/jpsd.v4i1.2965

Bentri, A., Adree, O., \& Putra, A. (2014). Implementasi Kurikulum 2013 di Sumatera Barat. Jurnal Penelitian Pendidikan, 5(1), 88-99.

https://doi.org/10.4324/9781315853178 
1185 Pengembangan Bahan Ajar Membaca Pemahaman Menggunakan Pojok Literasi pada Siswa di Kelas IV Sekolah Dasar - Taufina, Ahmad Zikri

DOI: https://doi.org/10.31004/basicedu.v4i4.523

Chandra, Mayarnimar, \& Habibi, M. (2018). Keterampilan Membaca Dan Menulis Permulaan Menggunakan Model Vark Untuk Siswa Sekolah Dasar. Jurnal Inovasi Pendidikan Dan Pembelajaran Sekolah Dasar, 2(1), 72-80. https://doi.org/https://doi.org/10.24036/0201 821100050-0-00011

Kemendikbud. (2013). Implementasi Kurikulum. Permendikbud. https://doi.org/10.1017/CBO9781107415324. 004

Muhammadi, Taufina, \& Chandra. (2018). LITERASI MEMBACA UNTUK MEMANTAPKAN NILAI SOSIAL SISWA SD. LITERA, 17(2), 202-212.

Mulyasa. (2013). uji kompetensi dan penilaian kinerja guru. In uji kompetensi dan penilaian kinerja guru.

Nopilda, L., \& Kristiawan, M. (2018). Gerakan Literasi Sekolah Berbasis Pembelajaran Multiliterasi Sebuah Paradigma Pendidikan Abad Ke- 21. JMKSP (Jurnal Manajemen, Kepemimpinan, Dan Supervisi Pendidikan), $3(2)$.

https://doi.org/10.31851/jmksp.v3i2.1862

Nur, L. (2018). The Implementation Of The Strengthening Character Education In Sdn 09 Mataram City, Nusa Tenggara Barat. Jurnal Pendidikan Karakter, 8(1), 17-28.

Prastowo, A. (2013). Pengembangan bahan ajar tematik. Yogyakarta: Viva Pres.

Purwanto, N. (2009). Prinsip-prinsip dan Teknik Evaluasi Pengajaran. PT Remaja Rosdakarya.

Ratih, M., \& Taufina. (2019). Pengembangan Bahan Ajar Membaca Permulaan Dalam Pembelajaran Tematik Dengan Model Vark (Visual, Auditory, Read/Write and Kinesthetic) Di Kelas I Sekolah Dasar. Jurnal Pemikiran Dan Pengembangan Sekolah Dasar (JP2SD), 7(2), 82-90. https://doi.org/ISSN : 2527-303
Suarni, N., Taufina, \& Zikri, A. (2019). Literasi Membaca Untuk Meningkatkan Karakter Positif Siswa Sekolah Dasar. Jurnal Basicedu, 3(2), 524-532.

Sugiyono. (2013). Metode Penelitian Pendidikan Pendekatan Kuantitaif, Kualitatif, dan R\&D. Metode Penelitian Pendidikan Pendekatan Kuantitaif, Kualitatif, Dan $R \& D$. https://doi.org/10.1007/s13398-014-0173-7.2

Suwardana, H. (2018). Revolusi Industri 4. 0 Berbasis Revolusi Mental. JATI UNIK: Jurnal Ilmiah Teknik Dan Manajemen Industri.

https://doi.org/10.30737/jatiunik.v1i2.117

Taufina, M. (2017). Developing Literacy Reading Teaching Materials by Using Big Books as an Effort to Build the 2nd Grade Students' Characters in Elementary School. Atlantis Press, 118, 835-844. https://doi.org/10.2991/icset-17.2017.136

Weriyanti, Firman, Taufina, \& Zikri, A. (2020). Pengembangan Bahan Ajar Tematik Terpadu Dengan Strategi Question Student Have Di Sekolah Dasar. Jurnal Basicedu, 3(2), 524 532. https://doi.org/10.31004/basicedu.v4i3.416 